\title{
REHABILITASI MEDIK PADA ANAK DENGAN LEUKEMIA LIMFOBLASTIK AKUT
}

\author{
Yenni \\ Bagian Ilmu Kedokteran Fisik dan Rehabilitasi Fakultas Kedokteran \\ Universitas Sam Ratulangi Manado \\ Email: thamrin_yenni@yahoo.com
}

\begin{abstract}
Acute lymphoblastic leukemia (ALL) is oftenly found in children as well as in adolescents. ALL occurs in 3-4 cases of 100,000 children. The specific etiology of ALL is still unknown, but it is related to a multifactorial process associated with genetic, immunology, environment, toxic substances, viral exposures, and ionization radiation. Clinical manifestations of ALL may include fatigue and weakness, palor, infections and febris that are not improved with antibiotics, easy bleeding or bruising, joint or bone pain, loss of appetite, weight loss, enlarged lymph nodes, cough, or difficulty of breathing, enlargement of the liver or spleen, swelling of the face and hands, headaches, and vomiting. Functional improvement is a goal for medical rehabilitation in patient with LLA. In general, cancer rehabilitation management aims to maintain body functions including mobilization and activity, nutrition, social support systems, and pain control. Moreover, the program is implemented in conjunction with specific interventions based on the affected organ systems.
\end{abstract}

Keywords: ALL, medical rehabilitation

\begin{abstract}
Abstrak: Leukemia limfoblastik akut (LLA) merupakan kanker yang sering terjadi pada anak-anak dan remaja. LLA terjadi pada 3-4 kasus dari 100.000 anak. Etiologi spesifik LLA belum diketahui, tetapi berhubungan dengan proses multifaktorial yang berkaitan dengan genetik, imunologi, lingkungan, toksik, paparan virus, ionization radiation. Manifestasi klinik leukemia dapat berupa kelelahan dan kelemahan, kulit pucat, infeksi dan demam yang tidak sembuh dengan antibiotik, mudah berdarah atau memar, nyeri sendi atau tulang, hilangnya nafsu makan dan turunnya berat badan, pembesaran kelenjar limfe, batuk atau kesulitan pernafasan, pembesaran hati atau limpa, pembengkakan muka dan tangan, sakit kepala, dan muntah Perbaikan status fungsional merupakan tujuan utama rehabilitasi medik pasien LLA. Penanganan rehabilitasi kanker secara umum ialah untuk memelihara fungsi meliputi mobilisasi, aktivitas, nutrisi, sistem pendukung sosial dan pengendalian rasa nyeri. Keseluruhan program ini diterapkan bersamaan dengan intervensi spesifik berdasarkan sistem organ yang terkena.
\end{abstract}

Kata kunci: LLA, rehabilitasi medik

Leukemia adalah kanker dari sel-sel pembentuk darah; sebagian besar merupakan kanker dari leukosit, tetapi dapat juga dapat berawal dari sel darah jenis lain. Leukemia dimulai di sumsum tulang yang merupakan tempat pembentukan sel-sel darah. Sel-sel darah dengan cepat dilepaskan ke dalam darah, kemudian dapat ke kelenjar getah bening, limpa, hati, sistem saraf pusat, dan organ lainnya. ${ }^{1}$ Salah satu jenis leukemia yang sering terjadi pada anak-anak dan remaja yaitu leukemia limfoblastik akut (LLA). ${ }^{2-5}$

Etiologi leukemia masih belum diketahui pasti. Para ahli menemukan bahwa terdapat hubungan antara leukemia 
dengan beberapa faktor risiko seperti faktor-faktor genetik, lingkungan (termasuk ionization radiation), dan orang tua yang peminum alkohol atau perokok. Pendapat lain mengemukakan bahwa lingkungan yang terpapar medan magnet perlu diperhitungkan, tetapi belum terbukti sebagai faktor penyebab LLA. ${ }^{1,3,5}$

Manifestasi klinik leukemia dapat berupa kelelahan dan kelemahan, pucat, infeksi dan demam yang tidak sembuh dengan antibiotik, mudah berdarah atau memar, nyeri sendi atau tulang, hilangnya nafsu makan dan turunnya berat badan, pembesaran kelenjar limf, batuk atau kesulitan pernafasan, pembesaran hati atau limpa, pembengkakan muka dan tangan, sakit kepala, serta muntah.,

Penanganan pasien LLA ialah pemberian kemoterapi dengan menggunakan protokol kemoterapi internasional, yaitu: induction, CNS preventive therapy, consolidation /reinduction, dan maintenance therapy. ${ }^{2,7-9}$ Pengobatan tersebut telah menjadi semakin kompleks dan membutuhkan suatu pengorganisasian yang cermat, keahlian, serta pengetahuan untuk mencapai hasil yang optimal. Anak-anak dengan LLA harus dirawat di pusat-pusat yang menyediakan personel khusus dan memberikan alat diagnostik dan strategi pengobatan yang up-to-date $2,10,11$ yang memerlukan koordinasi dari suatu tim multidispliner terdiri dari dokter spesialis anak dan tim rehabilitasi medik yang terdiri dari dokter spesialis rehabilitasi medik, fisioterapi, okupasi terapis, ortotis prostetis, psikolog, petugas sosial medic, serta perawat rehabilitasi. ${ }^{12}$ Penanganan rehabilitasi kanker secara umum ialah untuk memelihara fungsi tubuh yang meliputi mobilisasi, aktivitas, nutrisi, sistem pendukung social, dan pengendalian rasa nyeri. Keseluruhan program ini diterapkan bersamaan dengan intervensi spesifik berdasarkan sistem organ yang terkena. ${ }^{7}$

\section{DEFINISI}

Leukemia limfoblastik akut adalah salah satu tipe leukemia atau kanker pada leukosit dimana terjadi keganasan proliferasi sel-sel limfoblas muda dan ditunjukkan adanya jumlah limfoblas yang berlebihan di sumsum tulang, kelenjar limf, dan darah. ${ }^{1-5,9}$ LLA merupakan kelainan secara biologik sehingga karakteristik morfologik, imunologik, sitogenetik, biokimiawi, dan genetik molekular dari limfoblas perlu ditentukan dalam menegakkan diagnosis dan klasifikasi. ${ }^{9}$

\section{EPIDEMIOLOGI}

Angka kejadian LLA ialah 3-4 kasus per 100.000 anak. $^{1,2}$ Setiap tahun, di Amerika Serikat sekitar 2.500-3.000 anak, dan di Eropa sekitar 5000 anak menderita LLA. Insiden tertinggi terjadi pada usia 2-5 tahun., ${ }^{2,9}$ LLA merupakan keganasan yang tersering ditemukan pada usia $<15$ tahun, dan sekitar 25-30\% dari seluruh penyakit keganasan pada anak. ${ }^{2,3}$ Anak laki-laki mempunyai risiko leukemia yang lebih tinggi daripada anak perempuan, tetapi diagnosis leukemia pada tahun pertama kehidupan lebih sering pada anak perempuan dibandingkan anak laki-laki. ${ }^{3}$

Di negara-negara maju, insiden LLA pada anak 2-4 kali lipat dibandingkan ratarata insiden di negara-negara sedang berkembang. Hal ini bisa diakibatkan oleh perbedaan faktor lingkungan, genetik, dan akurasi diagnostik. $^{3}$

\section{ETIOLOGI}

Etiologi spesifik LLA belum diketahui, tetapi terdapat hubungan dengan proses multifaktorial yang berkaitan dengan genetik, imunologi, lingkungan, bahan toksik, dan paparan virus. Faktor lingkungan meliputi antara lain paparan ionizing radiation, bahan toksik kimia, herbisida dan pestisida. Pemakaian obat-obatan seperti kontrasepsi, diethylstilbestrol, dan amfetamin, rokok, konsumsi alkohol, kontaminasi zat kimia sebelum atau selama kehamilan mempunyai hubungan tidak konsisten dengan LLA. 2,3,10,11,13,14 Ionizing radiation dan paparan benzene merupakan faktor risiko yang berhubungan erat baik 
dengan LLA maupun leukemia mieloid akut. Beberapa penelitian melaporkan adanya kemungkinan hubungan antara medan elektromagnetik dari daya voltase tinggi dan perkembangan leukemia, tetapi penelitian yang lebih besar tidak mengonfirmasi hubungan tersebut. Sampai saat ini, penyebab leukemia umumnya tidak dapat diidentifikasi. ${ }^{11}$

\section{KLASIFIKASI}

WHO mengembangkan klasifikasi LLA berdasarkan sitogenetik dan karakteristik molekular. ${ }^{15}$ LLA terbagi atas 2 kelompok besar yaitu $B$ lymphoblastic leukemia/lymphoma (LLA-B) dan T lymphoblastic leukemia/lymphoma (LLAT). B lymphoblastic leukemia/lymphoma terdiri atas dua tipe, yaitu $B$ lymphoblastic leukemia/lymphoma not otherwise specified (NOS) dan B lymphoblastic leukemia/ lymphoma with reccurent genetic abnormalities, yang terdiri atas 7 subtipe. ${ }^{15}$

\section{PATOFISIOLOGI}

LLA dicirikan oleh proliferasi limfoblas imatur. Pada tipe leukemia akut, kerusakan mungkin pada tingkat sel punca limfopoietik atau prekursor limfoid yang lebih muda. Sel leukemia berkembang lebih cepat daripada sel normal, sehingga menjadi crowding out phenomenon di sumsum tulang. Perkembangan yang cepat ini bukan disebabkan oleh proliferasi yang lebih cepat daripada sel normal, tetapi selsel leukemia menghasilkan faktor-faktor yang selain menghambat proliferasi dan diferensiasi sel darah normal, juga mengurangi apoptosis dibandingkan sel darah normal. ${ }^{16}$

Perubahan genetik yang mengarah ke leukemia dapat mencakup: 1) Aktivasi gen yang ditekan (protogen) untuk membuat onkogen yang menghasilkan suatu produk protein yang mengisyaratkan peningkatan proliferasi; 2) Hilangnya sinyal bagi sel darah untuk berdiferensiasi; 3) Hilangnya gen penekan tumor yang mengontrol proliferasi normal; dan 4) Hilangnya sinyal apoptosis. $^{16}$

\section{MANIFESTASI KLINIS}

Gejala klinis umumnya berupa rasa tidak sehat, demam, pucat, kurang nafsu makan, berat badan menurun, malaise, kelelahan, nyeri tulang dan sendi, epistaksis dan cenderung terjadi perdarahan, rentan terhadap infeksi, serta sakit kepala. Tanda klinis yang ditemukan ialah kenaikan suhu tubuh, ekimosis atau petekie, splenomegali, hepatomegali, limfadenopati, dan anemia, dan letargi. ${ }^{1,6,9,16}$

\section{PEMERIKSAAN PENUNJANG}

Pada pemeriksaan laboratorium didapatkan anemia (pada 43\% kasus kadar hemoglobin $<7 \mathrm{~g} / \mathrm{dL}$ ) normokromik dan normositik (tanpa peningkatan kompensatorik dari retikulosit), trombositopenia (pada 28\% kasus hitung trombosit $<50.000 / \mathrm{mm}^{3}$ ), dan leukopenia atau leukositosis (pada 17\% kasus hitung white blood

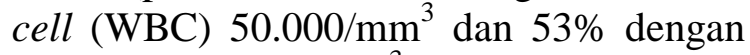
WBC $<10.000 \mathrm{sel} / \mathrm{mm}^{3}$ ). Peningkatan kadar asam urat darah dapat ditemukan karena pergantian seluler cepat pada pasien dengan peningkatan jumlah WBC. Kadar elektrolit kalium dan fosfat dapat meningkat dengan penurunan kompensatorik kalsium. ${ }^{16}$

Biopsi sumsum tulang melalui pungsi lumbal perlu dilakukan untuk menentukan proporsi sel punca dalam sumsum tulang. Dicurigai adanya suatu leukemia bila populasi sel punca $>5 \%$. Pengecatan sitokimiawi dapat membantu dalam menentukan jenis leukemia akut, limfoid atau mieloid. ${ }^{16}$ Immunophenotyping dilakukan untuk menganalisis antigen spesifik pada permukaan sel hematopoietik. Walaupun tidak terdapat antigen spesifik leukemia yang diidentifikasi, pola antigen permukaan sel dapat menunjukkan perbedaan antara leukemia limphoid dan mieloid. Analisis sitogenetik sumsum tulang bermanfaat untuk menentukan adanya non-random numerical dan abnormalitas kromosom struktural pada sel-sel leukemia; selain itu juga dapat membantu menentukan diagnosis, prognosis, dan evaluasi respon terhadap terapi. Foto dada dilakukan untuk 
skrining massa mediastinal (umumnya pada LLA sel T). ${ }^{16}$

\section{DIAGNOSIS BANDING}

Diagnosis banding LLA mencakup infeksi virus dan infeksi lainnya (infeksi mononukleosis, sitomegalovirus, dan leishmania), keganasan sumsum tulang lainnya (misalnya neuroblastoma, rabdomiosarkoma), penyakit vaskuler kolagen, dan penyakit hematologik seperti idiopathic thrombocytopenic purpura (ITP), anemia aplastik, dan kelainan sumsum tulang seperti Fanconi disease. ${ }^{6}$

Selain di dalam darah dan sumsum tulang, sel-sel punca leukemia (leukemic blasts) dapat juga menginfiltrasi organ lain berupa limfadenopati dan hepatosplenomegali, yang dapat dideteksi dengan pemeriksaan sitologik, histologik atau diagnostic imaging. ${ }^{6}$

\section{PENATALAKSANAAN}

Tujuan penanganan LLA ialah mencapai remisi hematologik dan klinis lengkap (complete remission, $\mathrm{CR}$ ) yang ditentukan dengan hilangnya semua tanda fisik dan kelainan sumsum tulang, restorasi hematopoiesis normal (netrofil 1500 $\mathrm{sel} / \mathrm{mm}^{3}$ dan trombosit $>100.000 \mathrm{sel} / \mathrm{mm}^{3}$ ). Setelah CR dicapai, pasien dipertahankan dalam CR kontinu. Secara umum, pasien anak dianggap sembuh setelah CR kontinu dicapai selama 5-10 tahun. Pemberian regimen dapat menginduksi CR pada 98\% kasus anak dengan LLA. Kasus anak yang tidak mencapai CR pada akhir induksi mendapatkan $16 \%$ overall event-free survival (EFS). Rata-rata penyembuhan pada kasus anak telah meningkat dari $<5 \%$ pada tahun 1960 sampai 90\% pada tahun $2005 .^{16}$

Pemberian prednison secara oral dengan dosis $60-80 \mathrm{mg} / \mathrm{m}^{2} / \mathrm{hari}$, selain itu bisa juga digunakan deksametason. Alkaloid vinca, bersama dengan steroid berperan penting dalam induksi remisi LLA. Dosis vincristine per minggu 1,5 $\mathrm{mg} / \mathrm{m}^{2}$ (dosis maksimal 2,0 $\mathrm{mg} / \mathrm{m}^{2}$ ). Alkaloid vinca yang lain seperti vinblastine dan vindesine masih kurang efektif dibandingkan vincristine. L-Asparaginase mempunyai aktivitas terbatas terhadap limfoblas. Daunorubicin memberikan aktivitas antileukemia yang bermakna; dosis kumulatif tidak boleh melebihi 300$400 \mathrm{mg} / \mathrm{m}^{2}$ pada anak dengan leukemia akut. Antagonis asam folat memulai revolusi terapi LLA, dan methotrexate dan mercaptopurine (antagonis purin) menjadi dasar maintenance kemoterapi LLA. Cytarabine arabinose (antagonis pyrimidine) berpotensi menginduksi remisi dan relaps LLA. Cyclophosphamide merupakan alkylating drug untuk LLA, dan efektif baik untuk LLA-T maupun LLA-B. ${ }^{17}$

\section{REHABILITASI MEDIK PADA LLA}

Perbaikan status fungsional merupakan tujuan utama rehabilitasi pasien LLA. $^{18}$ Penatalaksanaan LLA dilakukan oleh suatu tim antar disiplin ilmu; semua anggota tim bekerja sama untuk menilai dan mengidentifikasi masalah, menentukan tujuan terapi, dan memberikan intervensi. Anggota tim terdiri dari dokter spesialis anak, dokter spesialis rehabilitasi medik, fisioterapis, okupasi terapis, ortotis prostetis, psikolog, dan pekerja sosial medik. $^{12}$

\section{Terapi fisik}

Tujuan terapi fisik pada pasien keganasan anak ialah: preventif, untuk mencegah terjadinya gejala sisa yang menyebabkan disabilitas; restorasi, untuk memaksimalkan pulihnya sistem motorik pada pasien dengan defisit; suportif, untuk mendorong tingkat fungsional kemandirian tertinggi yang mungkin dicapai saat masih terdapat gejala sisa dan progresivitas disabilitas dapat diantisipasi; dan paliatif, untuk meningkatkan atau memelihara kenyamanan dan kemandirian pasien dengan terminal disease. Intervensi rehabilitasi membuat pasien dapat memelihara independensi dan mencegah komplikasi akibat tirah baring (imobilitas) karena waktu penanganan medis maupun perawatan yang lama. ${ }^{19}$ 
Pasien dengan keganasan hematologik mendapat manfaat dari program latihan fisik untuk pemeliharaan atau perbaikan dalam mengatasi kelelahan, meningkatkan aktivitas fisik, dan kebugaran. Komponen utama aktivitas fisik sehari-hari dan bentuk latihan umumnya ialah berjalan, dengan intensitas, durasi, dan frekuensi yang terkontrol; hal ini menjadi indikator kesehatan seseorang dan status kebugarannya. ${ }^{18}$ Dalam pelaksanaan terapi fisik dibutuhkan evaluasi kekuatan otot dan sensorik. Terapis harus menyadari bahwa anak-anak tidak tahan terhadap waktu latihan yang terlalu lama. Perhatian khusus diperlukan jika memberikan tahanan untuk evaluasi kekuatan pada pasien dengan trombositopenia yang berpotensi perdarahan dalam otot atau sendi. Program latihan strengthening dapat meliputi latihan isometrik, latihan aktif assisted, latihan aktif, atau latihan resistive. ${ }^{19}$

Pertimbangan khusus diberikan pada lingkup gerak sendi (LGS) ekstremitas yang terkena atau sisa tungkai yang telah diamputasi. Panjang otot-otot Hamstring bisa terbatas pada anak-anak yang tidak aktif atau berbaring dalam jangka waktu lama. Keterbatasan LGS dapat juga terlihat pada area dimana terjadi ekstravasasi obat kemoterapi. Penanganan pada keterbatasan atau kontaktur ialah latihan LGS pasif dan stretching. Perhatian khusus harus diberikan pada pasien dengan trombositopenia oleh karena adanya potensi terjadi perdarahan. ${ }^{19}$

Modalitas untuk menangani pasien dengan keganasan yaitu: transcutaneus electrical nerve stimulation (TENS), massage, pemanasan superfisial, yang bisa efektif dalam mengobati nyeri otot. ${ }^{19}$

\section{Terapi okupasi}

Pasien LLA membutuhkan terapi okupasi karena adanya komplikasi atau penyakit sekunder. ${ }^{20}$ Pemberian terapi okupasi ialah memaksimalkan kemampuan anak dalam aktivitas sehari-hari, peningkatan perkembangan ketrampilan, dan mengurangi dampak komplikasi penyakit. $^{21}$ Kelemahan otot dan atrofi sering terjadi pada pasien anak-anak dengan keganasan; sering disertai penurunan ketahanan kardiovaskuler akibat inaktivitas atau tirah baring yang terlalu lama. Latihan kardiovaskuler yang dapat diberikan bagi anak-anak ialah bermain bola, bersepeda ergometri, ambulasi progresif, atau aktivitas motorik seperti meloncat, melompat, skipping, dan berlari. ${ }^{19}$

Adanya disabilitas dapat memengaruhi kemampuan anak untuk bermain, mengurangi keceriaan, juga memengaruhi perasaan, kehilangan control, dan ketidakmampuan belajar. Dampaknya membuat anak kurang berminat untuk bermain, gangguan tingkah laku, serta gangguan kognitif, komunikasi, dan motorik. ${ }^{22}$ Terapis harus dapat memberikan tantangan sosial, kognitif, dan motorik, dengan memakai aktivitas permainan yang meningkatkan kemampuan pasien dan mencapai tujuan terapi. Sebagai contoh ialah recreational therapy; anak menunjukkan kemampuan motorik, ketangkasan, dan kekuatan otot yang meningkat. ${ }^{21}$

\section{Ortotik prostetik}

Alat-alat seperti splint, serial cast, dynamic brace, dan continus passive devices dapat dipakai untuk menangani kontraktur. Pada pasien dengan kelainan kulit seperti scar iminimalisasi dengan pemberian compression dressing. Mobilitas atau masalah gait sering terjadi pada pasien dengan keganasan akibat tirah baring yang lama atau amputasi. Latihan ambulasi progresif harus diterapkan pada pasien tersebut, termasuk assistive devices dan ortose yang diperlukan. ${ }^{19}$

\section{Psikologi}

Perkembangan emosional dan kepribadian seorang anak muncul antara usia 2-6 tahun. Secara umum, orang tua yang mempunyai anak dengan disabilitas fisik cenderung melindungi anaknya dan tidak mendorong anaknya menjadi mandiri. $^{23}$ Dukungan psikologi keluarga 
serta status emosional pasien dan keluarga harus diperhatikan karena berhubungan dengan stres berat yang akan muncul karena kematian anak akibat kanker. ${ }^{19}$ Faktor psikologi menjadi penting dan menentukan keberhasilan dalam hidup dibandingkan keparahan disabilitas yang diperoleh pasien. Dokter rehabilitasi medik perlu memasukkan kemampuan sosial dalam penilaian dari fungsi pasien dan rencana perbaikan tindakan yang diperlukan, seperti juga peresepan assistive devices atau latihan untuk mobilitas. ${ }^{24}$

\section{Sosial medik}

Pekerja sosial medik menilai situasi kehidupan penderita, membahas pilihan pengaturan keuangan dan urusan seharihari, memberi dukungan emosional pada pasien, keluarga, dan tim, serta bertindak sebagai perantara dalam hubungan antara pasien/keluarga dan tim. ${ }^{12}$

\section{PROGNOSIS}

Selama beberapa tahun terakhir telah terjadi perbaikan prognosis yang berkaitan dengan penelitian dan standar kemoterapi yang dihasilkan oleh pusat-pusat spesialis pediatrik onkologi. ${ }^{23}$ Dengan bantuan rehabilitasi medik maka sistem motorik dapat diperbaiki; hal ini menyokong tercapainya tingkat fungsional dengan kemandirian maksimal yang turut memperbaiki prognosis pasien LLA. $^{19}$ Prognosis terutama tergantung pada tipe keganasan dan perkembangan penyakit pada saat didiagnosis. Kasus anak dengan kekambuhan sering diberikan kemoterapi dosis tinggi dan transplantasi sumsum tulang. Secara umum prognosis untuk leukemia akut ialah baik dengan perkiraan kesembuhan $>65 \%$ dan 5-years survival mendekati $80 \%{ }^{15,23}$

\section{SIMPULAN}

Penatalaksanaan LLA dilakukan oleh suatu tim antar disiplin ilmu. Semua anggota tim bekerja sama untuk menilai dan mengidentifikasi masalah, menentukan tujuan terapi, dan memberikan intervensi, dengan tujuan utama perbaikan status fungsional.

\section{DAFTAR PUSTAKA}

1. Childhood leukemia overview - American Cancer Society. 2010 [cited 2013 Feb 20]; p. 2-14. Available from: http://www.cancer.org/acs/groups/cid/d ocuments/webcontent/003044-pdf.

2. Lanzkowsky P. Leukemia. In: Lanzkowsky $\mathrm{P}$, editor. Manual of Pediatric Hematology and Oncology (Fifth edition). New York: Elsevier Inc., 2011; p. 518.

3. Harila M. Health Related Quality of Life in Survivors of Childhood Acute Lymphoblastic Leukaemia [Thesis]. Oulu: University of Oulu; 2011.

4. Gaynon PS. Childhood acute lymphoblastic leukemia and relapse. US Special Population Pediatrics Review 2005. British Journal of Haematology. 2005;131:579-87.

5. Rubnitz JE, Pui CH. Childhood acute lymphoblastic leukemia. The Oncologist. 1997;2:374-380.

6. Smith OP, Hann IM. Clinical features and therapy of lymphoblastic leukemia. In: Arceci RJ, editor. Pediatric Hematology (Third edition). Oxford: Blackwell Publishing Ltd, 2006: p. 450-4.

7. Cifu DX. Rehabilitasi kanker. In: Garrison SJ, editor; Widjaja AC, penerjemah; Saputra V, Salim IN, editor bahasa Indonesia. Dasar-dasar Terapi dan Rehabilitasi Fisik. Philadelphia: Lippincott-Raven Publishers, 1995: p. 99-101.

8. Smith OP, Hann IM. Clinical features and therapy of lymphoblastic leukemia. In Arceci RJ, editor. Pediatric Hematology (Third Edtion). Oxford; Blackwell Publishing Ltd, 2006: p. 463-7.

9. Conter V, Rizzari C, Sala A, Chiesa R, Citterio M, Biondi A. Acute lymphoblastic leukemia. Orphanet Encyclopedia. December 2004: 1-13. [cited 2013 Feb 20]. Available from: https://www.orpha.net/data/patho/GB/u k-ALL.pdf 
10. Pui CH, Robison LL, Look AT. Acute lymphoblastic leukaemia. Lancet. 2008;371:1030-43.

11. Leather HL, Poon BB. Acute leukemias. In: Dipiro JT, editor. Pharmacotherapy A Pathophysiologic Approach (Seventh Edition). New York: The McGraw-Hill Companies Inc., 2008: p. 2263-5.

12. Cifu DX, Marskowski J. Kedokteran fisik dan rehabilitasi: Filsafat, masalah perawatan pasien dan evaluasi fisiatrik. In: Garrison SJ, editor; Widjaja AC, penerjemah; Saputra V, Salim IN, editor bahasa Indonesia. Dasar-dasar Terapi dan Rehabilitasi Fisik. Philadelphia, Lippincott-Raven Publishers. 1995: p. 1-4.

13. Robison LL, Sinks T, Smith AH, Smith M. Acute lymphocytic (lymphoblastic) Leukemia. In: Review and Recommendations of the Expert Panel. Fallon, Nevada, Nevada Division of Public and Behavioral Health. [cited 2013 May 5]. Available from: http://www.cdc.gov/nceh/clusters/fallon /4_ApdxB_Exppanelreport.doc).

14. Risk factors for acute lymphoblastic leukemia [Homepage on the Internet]. [cited 2013 March 23]. Available from: http://www.webmd.com/cancer/acutelymphoblastic-leukemia.

15. Lanzkowsky P. Leukemia. In: Lanzkowsky P, editor. Manual of Pediatric Hematology and Oncology (Fifth Edition). New York: Elsevier Inc., 2011; p. 524-32.

16. Leather HL, Poon BB. Acute leukemias. In: Dipiro JT, editor. Pharmacotherapy A Pathophysiologic Approach (Seventh Edition). New York: The McGraw-Hill
Companies Inc., 2008; p. 2260-5.

17. Smith OP, Hann IM. Clinical features and therapy of lymphoblastic leukemia. In: Arceci RJ, editor. Pediatric Hematology (Third Edition). Oxford: Blackwell Publishing Ltd, 2006; p. 460-7.

18. Knols RH, Bruin ED, Aufdemkampe G, Uebelhart D, Aaronson NK. Reliability of ambulatory walking activity in patients with hematologic malignancies. Archieve Physical Medicine Rehabilitation. 2009;9:58-65.

19. Morgan CR. Pediatric Oncology. In: Tecklin JS. Pediatric Physical Therapy. Philadelphia: Lippincott Williams \& Wilkins, 1999; p. 352-76.

20. Solomon JW, O'Brien JC. Introduction to pediatric conditions. In: Solomon JW, O’Brien JC, editors. Pediatric Skills for Occupational Therapy Assistants. St. Louis: Mosby Elsevier, 2006; p. 180-1.

21. O'Brien JC. Play and playfulness. In: Solomon JW, O’Brien JC, editors. Pediatric Skills for Occupational Therapy Assistants. St. Louis: Mosby Elsevier, 2006; p. 323-7.

22. Hollenbeck J. Childhood Occupations. In: Wagenfeld A, Kaldenberg J, editors. Foundations of Pediatric Practice for the Occupational Therapy Assistant. Philadephia: Slack Inc, 2005; p. 80-1.

23. Miall L, Rudolf M, Levene M. Childhood cancer. In: Paediatrics at a Glance. Massachusetts: Blackwell Publishing Company, 2003; p. 118-9.

24. Psychosocial aspects of childhood disabilities. In: Molnar GE, Alexander MA, editors. Pediatric Rehabilitation (Third Edition). Philadelphia: Hanley \& Belfus Inc., 1999; p. 114-22. 